\title{
EDITORIAL
}

\section{Power to Advocate for Health}

\author{
Kurt C. Stange, $M D, P b D$, Editor
}

Ann Fam Med 2010;8:100-107. doi: 10.1370/afm.1099.

$\mathrm{T}$ his is the seventh and final editorial in a series about integrative approaches to promoting health and personalized, high-value health care. ${ }^{1-6}$ This editorial examines how we can develop the power to act on key values, knowledge, and principles to advance health for people, communities, and the population. This article asks the following questions:

1. What is moral authority and why is it important?

2. How can we understand the process for developing moral authority to advocate for health?

3. How might we act differently as individuals and as organizations if we developed this moral authority?

The article concludes with a summary of the 7 pieces in this editorial series and an invitation to join the online discussion.

\section{WHAT IS MORAL AUTHORITY?}

Moral authority is the power to influence others to do the right thing. It is granted to those using their power for a larger good than promoting narrow self-interest, and originates from self-awareness, truthfulness, compassion, and from making personal sacrifice for a societal good. Moral authority comes from walking the talk-from living with congruence between thought, word, and action. It can be enhanced by having lived through a challenge with integrity and compassion. Moral authority requires the capacity to evaluate and decide on what is the right or wrong course of action. ${ }^{7}$ It does not require perfection, but continued striving.

Moral authority is shown by those who embody the message they speak. It is no accident that Gandhi, who said, "be the change you want to see," had great moral authority. While advocating for a free India, he would cancel a protest if only one person, even a person who did not acknowledge Gandhi as his leader, engaged in violence. Living simply and reflectively, and personally engaged in promoting the welfare of those who opposed his efforts, he embodied nonviolence, personal sacrifice, and working together toward a larger shared purpose. ${ }^{8}$

From the Dalai Lama to Viktor Frankl, Nelson Mandela, Amnesty International, Mother Theresa, Albert Einstein, and many others-those who have developed moral authority can inspire us to overcome short-term, narrowly selfish action to work toward a larger good that is both personal and transcendent.

But a hero model of moral authority is limited and often inaccurate. Elevating people to superhuman heights risks diminishing everyone else's sense of personal responsibility to advocate for a larger good. Hero models make for good tabloid fodder when the hero turns out to have human flaws, but promote the common good only when we are inspired to change our thought, word, and action.

A model of moral authority now emerging is less about heroes who fall and are blamed when things go wrong. Rather, what is emerging is a new focus on developing shared moral purpose. This focus is seen in cooperative movements, ${ }^{9-20}$ new approaches to economic development that emphasize solidarity, ${ }_{1}^{21,22}$ and a weariness with the unfulfilled promises of unfettered competition, efficiency, and so called productivity. ${ }^{23-27}$

\section{MORAL AUTHORITY IN MEDICINE}

The moral authority of physicians has been in decline for decades. Imber ${ }^{28}$ and Loxterkamp ${ }^{29-31}$ note that this decline parallels a shift away from a view of doctors as practitioners of a sacred vocation that includes but transcends the provision of health care services. At the same time, medicine has placed an increasing emphasis on delivering commodities of technology-driven and narrowly focused health care, ${ }^{27,32-34}$ rather than on working for the health of people and communities. ${ }^{1,35}$ As a result, not only has medicine's moral authority declined, so has its sense of shared moral purpose. ${ }^{23}$

Moral authority is diminished when power, particularly power that is conferred by others or society, is used for personal advancement. Many recent calls to reemphasize professionalism in medical training and conduct $^{27,28,36-42}$ emanate from a sense that the power conferred on physicians too often is used for selfadvancement and not enough for the larger public good.

As the focus of health care is less on promoting personal and community health ${ }^{27,33,43,44}$ and more on buying and selling narrow commodities and services, individuals, families, and communities find diminished 
options for a trusted partner in the pursuit of health. ${ }^{45}$ Despite some halting advances in shared decision making ${ }^{46,47}$ and patient-centered, ${ }^{48-50}$ relationship-centered, ${ }^{51-55}$ and goal-oriented ${ }^{56}$ care, a sense that something important has been lost lurks behind breathless assertions of the gains of the medical-industrial complex. ${ }^{57,58}$ Increasingly, health care in the modern age is an experience of loneliness and abandonment in a sea of technology and fragmentation. 1,59,60

What is trying to emerge in medicine, as in our larger society, is not a hero model of moral authority, but movement toward shared moral purpose. ${ }^{23}$ This shared purpose is less about promoting health care than it is about advancing health. It is less about physicians on white horses than it is about relationships and partnership. In the information age it is less about protecting professional privilege and knowledge than it is about developing shared understanding. ${ }^{6}$ It is about individual accountability, but also about collective responsibility and developing systems that support rather than hinder doing the right thing.

I believe that there are 3 reasons that moral authority of health care professionals, particularly physicians, has diminished. Medicine has (1) focused more on promoting health care rather than health and healing; (2) not openly considered the nature of power in health care; and (3) not recognized the developmental effects of thoughts and actions on the moral authority of individuals and organizations, and the ability of systems to support or encumber moral authority.

These 3 dimensions of moral authority and the opportunity to work together toward a shared moral purpose of promoting health are explained below.

\section{THE PROCESS OF DEVELOPING MORAL AUTHORITY TO ADVOCATE FOR HEALTH Promoting Health Care or Advancing Health and Healing?}

The well-intentioned focus of many health advocates and organizations on promoting health care often has the unintended consequence of reducing the health of individuals, communities, and populations. ${ }^{24,61-66}$ This is because access to adequate health care is only a small part of health, and because our view of health care has been narrow and fragmented. ${ }^{1}$ As a result, the prevailing view of improving health focuses more on delivering commodities, and less on healing, relationships, and meaning.

In contrast, the World Health Organization (WHO) articulated a focus on health when it stated:

The ultimate goal of primary health care is better health for all. WHO has identified 5 key elements to achieving that goal:
- Reducing exclusion and social disparities in health (universal coverage reforms)

- Organizing health services around people's needs and expectations (service delivery reforms);

- Integrating health into all sectors (public policy reforms)

- Pursuing collaborative models of policy dialogue (leadership reforms); and

- Increasing stakeholder participation. ${ }^{67}$

Implicit in this goal statement is raising the gaze of health advocates from diseases to people, and from developing systems just for the individual to developing systems that serve the interconnected good of the population. The WHO statement also has room for consideration of the social ${ }^{68}$ and environmental ${ }^{58,69-78}$ determinants of health, including education, access to employment, adequate housing and food, public safety, equitable resource distribution, sense of belonging in family and community, and clean air and water. Recognizing the failings of its own narrowly disease-specific initiatives, the WHO recently called for refocusing efforts on promoting primary health care. ${ }^{79-81}$ Because primary health care focuses on ongoing relationships with whole people and its boundary-spanning role in the health care system and community, ${ }_{1}^{2,82-84}$ it is positioned as the place where a renewal of vision and purpose can evolve. ${ }^{79-81,85}$

But what is health? Seedhouse ${ }^{86(\mathrm{p} 40)}$ identifies 4 theories of health that lead to 3 approaches to fostering health. The theories describe health differently:

- As an ideal state (such as the oft-quoted WHO definition that "health is a state of complete physical, mental and social well-being and not merely the absence of disease or infirmity." $)^{87}$

- As physical and mental fitness to accomplish social roles

- As a commodity that can be bought or given

- As personal strengths or abilities that can be either innate or developed, and which can be supported or lost

The 3 approaches to health improvement evolve from these theories:

- Sociological-is concerned with diverse factors that influence health and its inequalities

- Medical science-emphasizes clinics, hospitals, biology, statistics, and measurement of pathological conditions against normal standards, and is focused on disease causes and the effects of drugs and surgery to cure or prevent disease

- Humanist-regards health as a personal goal in which disease may coexist with health, recognizing people as complex whole, developing beings connected with physical and spiritual dimensions Seedhouse synthesized these theories and 
approaches by defining health as conditions that enable a person to work to achieve his or her biological and chosen potential. ${ }^{86(\mathrm{p} 84)}$

Fine and Peters ${ }^{88}$ define health as "the biological, social, and psychological ability that affords an equal opportunity for each individual to function in the relationships appropriate to his or her cultural context at any point in the life cycle." $88(\mathrm{p} 136)$

Berry goes even further in emphasizing the relationship, communal, and ecological aspects of health, declaring that health is membership in community. ${ }^{58}$

Egnew $^{89,90}$ and Scott, ${ }^{91,92}$ using both theory and empirical evidence, define healing as the transcendence of suffering.

Together, these thoughtful definitions move well beyond the common conflation of health with health care. They emphasize that health involves the capability to function to meet societal roles and personally meaningful goals that vary with innate capacities and different times in life. These definitions include connection with self ${ }^{93}$ and with transcendence of self, ${ }^{94}$ and thus allow for health-promoting efforts that consider the good of the whole community and include the possibility of a meaningful death. ${ }^{89,90,95}$

I would simplify the definition as follows: Health is the ability to develop meaningful relationships and pursue a transcendent purpose in a finite life.

\section{Understanding the Nature of Power in Health Care}

Moral authority to advocate for health requires focusing different kinds of power on promoting health. While not specifically addressing moral authority, Howard Brody is one of the few philosophers/ethicists to consider the use of power in medicine. Drawing on the work of Patterson, ${ }^{96}$ Siegler and Osmond ${ }^{97}$ and Starr, ${ }^{98,99}$ Brody identifies 3 kinds of power ${ }^{100}$ :

Charismatic power stems from a physician's personal characteristics, such as character and charisma. These qualities are not transferable and are an important potential source of a healing beyond the technical aspects of health care. ${ }^{101,102}$

Social power comes from the societal and community status of the physician. Part of this power comes from the implied contract that gives the profession authority over medical truth in return for using that authority to reduce suffering from illness and to promote health. Social power also can include cultural power if physicians are drawn from higher societal classes.

Aesculapian power comes from training in the discipline of medicine. It is based on knowing and being able to apply specific facts, skills, art, and craft affecting health and illness. This power is impersonal, transferable, and independent of social status or class.
In considering the responsible exercise of power, Brody asks us to take into account whether power is owned, aimed, and shared. Power that is owned is acknowledged, and responsibility is taken for its ethical use. The act of sharing power contains within it the possibility for correcting many potential abuses of power. Aiming power requires identification of a useful target for that aim. Brody's book The Healer's Power ${ }^{100}$ contains a much fuller consideration of the implications of power and its use in medicine.

Regarding the development of moral authority, it is helpful to acknowledge (own) the sources of power to advocate for health. This acknowledgment can help us as individuals and organizations to develop our power to work toward a larger good than immediate, apparent self-interest. If the different kinds of power are aimed at promoting health in ways that are meaningful to individuals, communities, and populations, the capacity for moral authority is enhanced. If, however, power is focused on promoting narrow aspects of health care without collaborative consideration of how those health care services or systems affect health, the effect is to diminish moral authority, particularly if the self-interest of the powerful is advanced. If shared power is widely shared, if owned power is focused on a larger good than self-interest, and if aimed power is directed at advancing personal and population health, shared moral purpose to advocate to optimize health for all can be fostered.

\section{DEVELOPMENT OF MORAL AUTHORITY}

Moral authority doesn't just happen. It can be bestowed. It evolves. It can be developed through thoughts, words, and actions-both small and largeacross owned, aimed, and shared power.

In individuals, moral authority is developed by reflection, truthfulness, compassion, and sacrifice. Moral authority to advocate for health is available to people outside health care, particularly those who have relevant vision, expertise, or experience. Individual health care workers seeking to develop their moral authority to advocate for health can develop themselves beyond the narrow technician role ${ }^{103}$ that is increasingly the main focus of health care training. This growth involves developing as professionals who see their contract with society as evoking responsibility for the person and the common good more than pursuing privilege for the profession. ${ }^{29,104-107}$ Further growth involves developing as leaders and healers and citizens focused on meaningful relationships. Biomedical health care can foster moral authority when it moves beyond clinician-centered care to patient-centered care to relationship-centered care to goal-oriented care. ${ }^{4}$ Each step in this path transcends and includes the one before, 
bringing together the clinician's and patient's knowledge to develop relationships that enable health that is meaningful to the goals of the patient, family, and community. ${ }^{56,91}$

Health care and health promotion teams can foster their moral authority to develop shared moral purpose $\mathrm{e}^{23}$ by developing from multidisciplinary groups in which members work in their own realms, to interdisciplinary teams working together on the common problem of fostering health, to transdisciplinary teams that develop shared common understanding, to healthy communities that go beyond disciplinary roles to live, learn, and work together to foster healthy and healing relationships. ${ }^{108,109}$

Organizations evolve moral authority along a similar path that involves interpersonal reflection, truthfulness, and development of shared experience and understanding, ${ }^{9}$ which leads to shared goals and the possibility of both shared sacrifice and shared abundance. ${ }^{110-113}$

Health care systems can develop moral authority when they include disease-focused systems but transcend that focus to also include patient-oriented systems that foster relationships and healthy and healing environments. ${ }^{4}$ Health care systems develop the ability to enable moral authority when they move beyond supporting technical care to develop systems that help integrate and prioritize care and focus on fostering healing and health. Individuals' and organizations' ability advocate for health is advanced when these systems both support disease-specific, technical, and vertical integration of care for specific diseases ${ }^{114,115}$ and support horizontal integration, ${ }^{64,65,116,117}$ personalization, and prioritization ${ }^{2-4}$ among diverse aspects of health care and the social and environmental determinants of health. ${ }^{50,58,68,72,118,119}$ These integrating, personalizing, and prioritizing functions are central to primary care, but they can also be enacted when more narrowly defined interests raise their gaze from the disease, the product, or the technique to the person, and from the person to the community and population. ${ }^{2-4,100}$

Although it is harder to do the right thing in a wrong system, systems that are unsupportive occasionally can serve as the stimulus for doing good. Broken systems sometimes can even stimulate the development of a Gandhi or a Médecins Sans Frontières. This happens through personal work and then interpersonal efforts to progress from awareness and reflection to truthfulness, compassion, and shared goals that enable personal and shared sacrifice for a larger good.

\section{ACTING DIFFERENTLY AS INDIVIDUALS AND AS ORGANIZATIONS}

How might individuals and organizations act differently to evolve shared moral purpose that improves health as the ability to develop meaningful relationships and pursue a transcendent purpose in a finite life?

As individuals, we might make time for reflection as well as for action-taking time each day to increase our awareness of the diverse factors affecting health and how they interact, contemplating how our thoughts, words, and actions can contribute to health and healing. The societal focus on competition, efficiency, and productivity makes this difficult. We might do it anyway, focusing that energy on personal spiritual development and service. ${ }^{94}$ To do so, we might follow any number of ancient or modern practices, developing our capacity for discernment and compassion along the way. ${ }^{52,120-122}$ We might work to embody this awareness, turning it into action to improve health for those in our circles of influence.

If we work in health care, we might consider where to aim our medical knowledge in the information age, when knowledge is common but understanding and wisdom are rare. ${ }^{6}$ We might participate in a new kind of knowledge generation, in which personalized medicine $^{123-128}$ means knowing the person, ${ }^{1,2,4}$ not just their genome. Where personal knowing is used to integrate and prioritize care to promote healing and health, ${ }^{4}$ not just to tailor pharmacotherapy. ${ }^{129}$ In deciding how to live our lives, we might begin to balance self-effacement and self-sacrifice with relationships and interests outside medicine, ${ }^{36}$ and in so doing, move from the heroic vision of the healer to being a fellow traveler with our patients/friends.

Working in small teams and large groups, we might look for opportunities for moral leadership ${ }^{130}$ in working with others toward system change, ${ }_{1}^{131}$ in both the larger systems and those in our own practices and communities. We might seek to develop new partnerships with patients, colleagues, and community organizations. We might focus these partnerships on fostering the emergence of new models of health care $^{132-135}$ and health promotion to emerge ${ }^{136,137}$ - working together to develop the awareness and truthfulness that lead to common experience and understanding that facilitate shared goals and the possibility of shared sacrifice that generates collective abundance. ${ }^{111-113,138,139}$

As organizations, we might work to refocus our mission on advocating not only for the narrow interests of members, but for the health of the people our members serve. A nonprofit organization that declines funds from commercial, health-related entities has the potential to develop great moral authority. When organizations open themselves to diverse interests in promoting health, they can ignite the idealism and sense of purpose of people yearning to work toward a larger good. ${ }^{140-142}$ Such partnerships can bring together those who are disenfranchised by the current medi- 
cal-industrial complex ${ }^{143}$ to develop coalitions to truly restructure health care, not to feed health care industry special interests, ${ }^{27,33,44}$ but to foster health and sustainable, evolvable health care ${ }^{135}$ and to support the social and environmental enablers of health. ${ }^{68,118}$

This is the hard work of redesigning practice. This is the hard and personally transforming work of developing teams. ${ }^{144}$ This is the hard and political work of redesigning systems, organizations, and communities. . $^{9} 53,145-148$ This is the work of reinventing what it means to provide personalized health care and promote health in the information age. ${ }^{149-151}$ Health care in the United States and around the world is nearing a flash point at which a rapid cycle of creative destruction and renewal is poised to reward innovation focused on providing value in promoting health. ${ }^{5}$

This work is exciting and worthwhile. It is worthy of both generalists ${ }^{66,152}$ and those with narrower expertise. $^{2}$ It is the multilevel work needed to foster shared moral purpose to advance health.

\section{MOVING FORWARD IN USING GENERALIST KNOWLEDGE TO PROMOTE HEALTH AND HIGH-VALUE HEALTH CARE}

The articles in this editorial series address the following

- The problem of fragmentation ${ }^{1}$

- The generalist approach: ways of being, knowing, seeing, thinking, and acting that foster integration, prioritization, and personalization of health care $^{2}$

- The paradox of primary care: how despite apparently poorer care of individual diseases compared with secondary or tertiary care, systems based on primary care have similar quality of disease care for whole people, better quality of care for populations, lower cost and less inequality ${ }^{3}$

- A science of connectedness: how understanding development across multiple levels of health care can enable the higher level generalist functions that provide added value ${ }^{4}$

- Making sense of both inertia and radical changes in health care systems by understanding adaptiverenewal cycles ${ }^{5}$

- Ways of knowing, learning, and developing that advance from data to information to knowledge to (shared) understanding to wisdom ${ }^{6}$

- How moral authority to advocate for health can be understood and developed.

In the ongoing Annals online discussion, each article has stimulated both criticism and amplification that help to advance understanding and application of generalist knowledge. This knowledge is vital if health care is to evolve in ways that foster health. This knowledge is deeply understood but often lost as we live courses of action based on more narrowly construed concepts.

I invite readers to comment online by clicking on Submit a Comment in the upper-right corner of each article. If your comment relates to the entire series, please comment on this last article on moral authority. A limited number of print copies of this series, including comments received before April 30, 2010, will be published. Please send requests for print copies to sac@cwru.edu .

To read or post commentaries in response to this article, see it online at http://www.annfammed.org/cgi/content/full/8/2/100.

Key words: Moral authority; ethics, health, health care; primary health care

Submitted February 4, 2010; submitted, revised, February 8, 2010; accepted February 18, 2010.

Funding support: This work is supported in part by a Clinical Research Professorship from the American Cancer Society. A number of the ideas in this editorial series were developed during an Overseas Visiting Scholarship at St. John's College, Cambridge University, sponsored by Professor Ann Louise Kinmonth during the autumn of 2007. Support also has been provided by the Gertrude Donnelly Hess, MD, Professorship at Case Western Reserve University. Dr Hess was a pioneering general practitioner in Cleveland before dying 2 weeks short of her 102nd birthday.

Acknowledgments: I am grateful to Heide Aungst, Howard Brody, Ken Frisof, John Geyman, Robin Gotler, Robert Graham, Larry Green, David Loxterkamp, Will Miller, Paul Lyons, Victoria Palmer, and Ross Upshur for their very helpful comments on earlier versions of this piece. Although the shortcomings of this article are mine, I want to particularly acknowledge their kindness and several specific contributions.

Victoria Palmer's work on the concept of shared moral purpose was formative. Paul Lyons exploded the hero model of moral authority and helped reconcile apparent generational differences in sources of moral authority. John Geyman reminded me that despite the academic rhetoric, moral authority comes down to a personal set of practices, values, and motivations that lead us to stand up to do the right thing -it is about action, not words. Larry Green and Robert Graham showed me how much the current crisis in moral authority is about finding ways to personalize health care in the information age-how to organize health care to involve care and not just commodity. Ken Frisof pointed out the need for moral leadership and defined advocacy as making the case for others who do not have a strong voice. Robin Gotler helped to increase the accessibility of the writing, as she has done on each article in this series. Will Miller's suggestions on the next-to-final draft were subtle but profound. Howard Brody pointed out a major error in a prior draft in my interpretation of his work on power. I leave it to him and to other readers to use the online commentary to correct remaining errors and to provide additional information and interpretations.

\section{References}

1. Stange KC. The problem of fragmentation and the need for integrative solutions. Ann Fam Med. 2009;7(2):100-103.

2. Stange KC. The generalist approach. Ann Fam Med. 2009;7(3): 198-203.

3. Stange KC, Ferrer RL. The paradox of primary care. Ann Fam Med. 2009;7(4):293-299. 
4. Stange KC. A science of connectedness. Ann Fam Med. 2009;7(5): 387-395.

5. Stange KC, Ferrer RL, Miller WL. Making sense of health care transformation as adaptive-renewal cycles. Ann Fam Med. 2009; $7(6): 484-487$.

6. Stange KC. Ways of knowing, learning, and developing. Ann Fam Med. 2010;8(1):4-10.

7. Gert B. The Moral Rules: A New Rational Foundation for Morality. New York, NY: Harper and Row; 1970.

8. Easwaran E. Gandhi the Man. 3rd ed. Petaluma, CA: Nilgiri Press; 1997.

9. Block P. Community: The Structure of Belonging. San Francisco, CA: Berret-Koehler Publishers, Inc; 2008.

10. Rasmussen WD. Taking the University to the People: Seventy-Five Years of Cooperative Extension. Ames, IA: lowa State University Press; 1989

11. Nelson EC, Kirk JW, Bise BW, et al. The Cooperative Information Project: Part 1: A sentinel practice network for service and research in primary care. J Fam Pract. 1981;13(5):641-649.

12. Foster-Fishman PG, Berkowitz SL, Lounsbury DW, Jacobson S, Allen NA. Building collaborative capacity in community coalitions: a review and integrative framework. Am J Community Psychol. 2001;29(2):241-261.

13. Mizrahi T, Rosenthal BB. Complexities of coalition building: leaders' successes, strategies, struggles, and solutions. Soc Work. 2001;46(1):63-78.

14. Starfield B. Public health and primary care: challenges and opportunities for partnerships. Ethn Dis. Summer 2003;13(3 Suppl 3): S3-12-13.

15. Callahan CM, Boustani MA, Unverzagt FW, et al. Effectiveness of collaborative care for older adults with Alzheimer disease in primary care: a randomized controlled trial. JAMA. 2006;295(18):2148-2157.

16. Barrett F, Fry R. Appreciative Inquiry: A Positive Approach to Building Cooperative Capacity. Chagrin Falls, OH: Taos Institute Publications; 2005.

17. Burns LR, Alexander JA, Shortell SM, et al. Physician commitment to organized delivery systems. Med Care. 2001;39(7)(Suppl 1): 19-129.

18. Christensen CM, Marx M, Stevenson HH. The tools of cooperation and change. Harv Bus Rev. 2006;84(10):72-80, 148.

19. Larson EB. Group Health Cooperative-one coverage-and-delivery model for accountable care. N Engl J Med. 2009;361(17):1620-1622.

20. Westfall JM, Fagnan LJ, Handley M, et al. Practice-based research is community engagement. J Am Board Fam Med. 2009;22(4):423-427.

21. Allard J, Davidson C, Matthaei J, eds. Solidarity Economy: Building Alternatives for People and Planet. Chicago, IL: ChangeMaker Publications; 2008

22. Patel R. The Value of Nothing: How to Reshape Market Society and Redefine Democracy. 1st Picador ed. New York, NY: Picador; 2009.

23. Palmer V. Narratives Beyond Civility: The Role of Moral Protest and Cooperation in Ethical Communities [PhD thesis]. Brisbane, Australia: Centre for Social Change Research, School of Humanities and Human Services, Queensland University of Technology; 2006.

24. Heath I, Rubenstein A, Stange KC, van Driel M. Quality in primary health care: A multidimensional approach to complexity. BMJ. 2009;338:b1242.

25. Heath I, Hippisley-Cox J, Smeeth L. Measuring performance and missing the point? BMJ. 2007;335(7629):1075-1076.

26. Geyman JP. Moral hazard and consumer-driven health care: a fundamentally flawed concept. Int J Health Serv. 2007;37(2):333-351.

27. Geyman J. The Corrosion of Medicine: Can the Profession Reclaim its Moral Legacy? Monroe, ME: Common Courage Press; 2008.
28. Imber JB. Trusting Doctors: The Decline of Moral Authority in American Medicine. Princeton, NJ: Princeton University Press; 2008.

29. Loxterkamp D. A vow of connectedness: views from the road to Beaver's farm. Fam Med. 2001;33(4):244-247.

30. Loxterkamp D. A Measure of My Days: The Journal of a Country Doctor. Hanover, NH: University Press of New England; 1997.

31. Loxterkamp D. Doctors' work: eulogy for my vocation. Ann Fam Med. 2009;7(3):267-268.

32. Heath I. Patients are not commodities. BMJ. 2006;332(7545): 846-847.

33. Geyman J. The Corporate Transformation of Health Care: Can the Public Interest Still Be Served? New York, NY: Springer Publishing Company; 2004.

34. Geyman JP. Disease management: panacea, another false hope, or something in between? Ann Fam Med. 2007;5(3):257-260.

35. Stange KC. The paradox of the parts and the whole in understanding and improving general practice. Int J Qual Health Care. 2002;14(4):267-268.

36. McCullough LB. The physician's virtues and legitimate self-interest in the patient-physician contract. Mt Sinai J Med. 1993;60(1):11-14.

37. Sox HC; ABIM Foundation. American Board of Internal Medicine; ACP-ASIM Foundation. American College of Physicians-American Society of Internal Medicine; European Federation of Internal Medicine. Medical professionalism in the new millennium: a physician charter. Ann Intern Med. 2002;136(3):243-246.

38. Quaintance JL, Arnold L, Thompson GS. What students learn about professionalism from faculty stories: an "appreciative inquiry" approach. Acad Med. 2010;85(1):118-123.

39. Schachter M. Professionalism, again. Med Educ. 2009;43(9):925.

40. Green M, Zick A, Makoul G. Defining professionalism from the perspective of patients, physicians, and nurses. Acad Med. 2009; 84(5):566-573.

41. Rabow MW, Wrubel J, Remen RN. Promise of professionalism: personal mission statements among a national cohort of medical students. Ann Fam Med. 2009;7(4):336-342.

42. Wilkinson TJ, Wade WB, Knock LD. A blueprint to assess professionalism: results of a systematic review. Acad Med. 2009;84(5):551-558.

43. Brody H. Hooked: Ethics, the Medical Profession, and the Pharmaceutical Industry. Lanham, MD: Rowman \& Littlefield Publishers, Inc; 2007.

44. Geyman J. Shredding the Social Contract: The Privatization of Medicare. Monroe, ME: Common Courage Press; 2006.

45. Leopold N, Cooper J, Clancy C. Sustained partnership in primary care. J Fam Pract. 1996;42(2):129-137.

46. Frosch DL, Kaplan RM. Shared decision making in clinical medicine: past research and future directions. Am J Prev Med. 1999; 17(4):285-294

47. Rimer BK, Briss PA, Zeller PK, Chan EC, Woolf SH. Informed decision making: what is its role in cancer screening? Cancer. 2004 101(5)(Suppl):1214-1228.

48. Epstein RM, Franks P, Fiscella K, et al. Measuring patient-centered communication in patient-physician consultations: theoretical and practical issues. Soc Sci Med. 2005;61(7):1516-1528.

49. Epstein RM, Franks P, Shields CG, et al. Patient-centered communication and diagnostic testing. Ann Fam Med. 2005;3(5):415-421.

50. Borrell-Carrió F, Suchman AL, Epstein RM. The biopsychosocial model 25 years later: principles, practice, and scientific inquiry. Ann Fam Med. 2004;2(6):576-582.

51. Beach MC, Inui T; Relationship-centered care research network Relationship-centered care. A constructive reframing. J Gen Intern Med. 2006;21(Suppl 1):S3-S8.

52. Epstein RM. Mindful practice in action (i): Technical competence, evidence-based medicine and relationship-centered care. Fam Syst Health. 2003;21(1):1-10. 
53. Miller WL, Crabtree BF, Nutting PA, Stange KC, Jaén CR. Primary care practice development: A relationship-centered approach. Ann Fam Med. 2010;8 (suppl2). In press.

54. Safran DG, Miller W, Beckman H. Organizational dimensions of relationship-centered care. Theory, evidence, and practice. J Gen Intern Med. 2006;21(Suppl 1):S9-S15.

55. Stange KC, Miller WL, MCWhinney I. Developing the knowledge base of family practice. Fam Med. 2001;33(4):286-297.

56. Mold JW, Blake GH, Becker LA. Goal-oriented medical care. Fam Med. 1991;23(1):46-51.

57. Deyo RA, Patrick DL. Hope or Hype. The Obsession With Medical Advances and the High Cost of False Promises. New York, NY: AMACOM; 2005.

58. Berry W. Health is membership. In: Wirzba N, ed. The Art of the Commonplace : The Agrarian Essays of Wendell Berry. Berkeley, CA: Counterpoint; 2002:144-158.

59. Grady D. Cancer patients, lost in a maze of uneven care. New York Times. July 29, 2007.

60. Hoffman J. Awash in information, patients face a lonely, uncertain road. New York Times. August 14, 2005.

61. van Weel C, De Maeseneer J, Roberts R. Integration of personal and community health care. Lancet. 2008;372(9642):871-872.

62. Rohde J, Cousens S, Chopra M, et al. 30 years after Alma-Ata: has primary health care worked in countries? Lancet. 2008;372(9642): 950-961.

63. Lawn JE, Rohde J, Rifkin S, Were M, Paul VK, Chopra M. Alma-Ata 30 years on: revolutionary, relevant, and time to revitalise. Lancet. 2008;372(9642):917-927.

64. De Maeseneer J, van Weel C, Egilman D, Mfenyana K, Kaufman A Sewankambo N. Strengthening primary care: addressing the disparity between vertical and horizontal investment. Br J Gen Pract. 2008;58(546):3-4.

65. Thomas P, Meads G, Moustafa A, Nazareth I, Stange KC. Combined vertical and horizontal integration of health care - a goal of practice based commissioning. Qual Prim Care. 2008;16(6):425-432.

66. Gunn JM, Palmer VJ, Naccarella L, et al. The promise and pitfalls of generalism in achieving the Alma-Ata vision of health for all. Med J Aust. 2008;189(2):110-112.

67. World Health Organization. Primary Health Care. Geneva; WHO; 2010.

68. World Health Organization. Commission on Social Determinants of Health - Final Report. Geneva: WHO; 2008.

69. Berry W. Life Is a Miracle: An Essay Against Modern Superstition. Washington, DC: Counterpoint; 2000.

70. Berry W. Is Life a Miracle? Citizenship Papers. 1st pbk. ed. Washington, DC: Shoemaker \& Hoard; 2004:181-189.

71. Lichtenstein P, Holm NV, Verkasalo PK, et al. Environmental and heritable factors in the causation of cancer-analyses of cohorts of twins from Sweden, Denmark, and Finland. N Engl J Med. 2000; 343(2):78-85.

72. Van Newkirk A. Bioregions: Towards bioregional strategy for human cultures. Environ Conserv. 1975;2(2):108-109.

73. Folke C, Carpenter S, Elmqvist T, et al. Resilience and Sustainable Development: Building Adaptive Capacity in a World of Transformations. Paris: International Council for Science; 2002.

74. Hiatt RA, Breen N. The social determinants of cancer: a challenge for transdisciplinary science. Am J Prev Med. 2008;35(2)(Suppl): S141-S150.

75. Berry W. Citizenship Papers. 1st pbk. ed. Washington, DC: Shoemaker \& Hoard; 2004

76. Devall B. Simple in Means, Rich in Ends: Practicing Deep Ecology. Salt Lake City, UT: Peregrine Smith Books; 1988.
77. Best A, Stokols D, Green LW, Leischow S, Holmes B, Buchholz K. An integrative framework for community partnering to translate theory into effective health promotion strategy. Am J Health Promot. 2003;18(2):168-176.

78. Lynch K. Managing the Sense of a Region. Cambridge: MIT Press; 1976.

79. World Health Organization. Primary Health Care - Now More Than Ever. The World Health Report. Geneva, Switzerland: WHO; 2008.

80. Chan M. Return to Alma-Ata. Lancet. 2008;372(9642):865-866.

81. Chan M. Primary health care as a route to health security. Lancet. 2009;373(9675):1586-1587.

82. Starfield B. Primary Care: Balancing Health Needs, Services, and Technology. Rev. ed. New York, NY: Oxford University Press; 1998.

83. Donaldson MS, Yordy KD, Lohr KN, Vanselow NA, eds. Primary Care-America's Health in a New Era. Washington DC: National Academy Press; 1996.

84. Stange KC, Jaén $(R$, Flocke SA, Miller WL, Crabtree BF, Zyzanski SJ The value of a family physician. J Fam Pract. 1998;46(5):363-368.

85. Wibulpolprasert S, Tangcharoensathien V, Kanchanachitra C. Three decades of primary health care: reviewing the past and defining the future. Bull World Health Organ. 2008;86(1):3.

86. Seedhouse D. Health: The Foundations For Achievement. 2nd ed. New York, NY: Wiley; 2001.

87. World Health Organization. Definition of Health. Geneva: World Health Organization; 1948.

88. Fine M, Peters JW. The Nature of Health: How America Lost, and Can Regain, a Basic Human Value. Abingdon, Oxfordshire: Radcliffe Publishing Limited; 2007.

89. Egnew TR. The meaning of healing: transcending suffering. Ann Fam Med. 2005;3(3):255-262.

90. Egnew TR. Suffering, meaning, and healing: challenges of contemporary medicine. Ann Fam Med. 2009;7(2):170-175.

91. Scott JG, Cohen D, Dicicco-Bloom B, Miller WL, Stange KC, Crabtree BF. Understanding healing relationships in primary care. Ann Fam Med. 2008;6(4):315-322.

92. Scott JG, Scott RG, Miller WL, Stange KC, Crabtree BF. Healing relationships and the existential philosophy of Martin Buber. Philos Ethics Humanit Med. 2009;4:11.

93. Sulmasy DP. The Rebirth of the Clinic: An Introduction to Spirituality in Health Care. Washington, DC: Georgetown University Press; 2006.

94. Easwaran E. Your Life Is Your Message. Finding Harmony With Yourself, Others, and the Earth. Petaluma, CA: Nilgiri Press; 1992.

95. Farber SJ, Egnew TR, Herman-Bertsch JL, Taylor TR, Guldin GE. Issues in end-of-life care: patient, caregiver, and clinician percep tions. J Palliat Med. 2003;6(1):19-31.

96. Patterson TT. Management Theory. London: Business Publications; 1966.

97. Siegler M, Osmond H. Aesculapian authority. Hastings Center Studies. 1973;1(2):41-52.

98. Starr P. The Social Transformation of American Medicine. New York, NY: Basic Books, Inc.; 1982.

99. Starr P. The Social Origins of Professional Sovereignty. New York: Harper Collins Publishers; 1982:3-29.

100. Brody H. The Healer's Power. New Haven, CT: Yale University Press; 1992.

101. Brody H. Placebos and the Philosophy of Medicine. Chicago, IL: University of Chicago Press; 1980.

102. Brody H. The Placebo Response: How You Can Release the Body's Inner Pharmacy For Better Health. New York, NY: HarperCollins Publishers; 2000.

103. Robinson WD, Priest LA, Susman JL, Rouse J, Crabtree BF. Technician, friend, detective, and healer: family physicians' responses to emotional distress. J Fam Pract. 2001;50(10):864-870. 
104. Woolf SH, Stange KC. A sense of priorities for the healthcare commons. Am J Prev Med. 2006;31(1):99-102.

105. Loxterkamp D. Saving Fred: what family practice means to medicine. BMJ. 2000;321(7276):1567-1568.

106. Pellegrino ED, Thomasma DC. The Virtues in Medical Practice. New York, NY: Oxford University Press; 1994.

107. Pellegrino ED. What the philosophy of medicine is. Theor Med Bioeth. 1998;19(4):315-336.

108. Crabtree BF, Miller WL, Adison RB, Gilchrist VJ, Kuzel A, eds. Exploring Collaborative Research in Primary Care. Thousand Oaks, CA: Sage Publications; 1994.

109. Stange KC. Journal of participatory medicine: setting its sights on a community of practice. J Participat Med. Vol (Oct):Launch Issue; 2009.

110. Easwaran E. Conquest of Mind. Tomales, CA: Nilgiri Press; 1988.

111. Post SG. Unlimited Love: Altruism, Compassion, and Service. Philadelphia, PA: Templeton Foundation Press; 2003.

112. Post SG, ed. Altruism and Health: Perspectives From Empirical Research. Oxford: Oxford University Press; 2008.

113. Post SG, Underwood LG, Schloss JP, Hurlbut WB, eds. Altruism and Altruistic Love. New York, NY: Oxford University Press; 2002.

114. Ouwens M, Hulscher M, Hermens R, et al. Implementation of integrated care for patients with cancer: a systematic review of interventions and effects. Int J Qual Health Care. 2009;21(2):137-144.

115. Ouwens M, Wollersheim H, Hermens R, Hulscher M, Grol R. Integrated care programmes for chronically ill patients: a review of systematic reviews. Int J Qual Health Care. 2005;17(2):141-146.

116. Stange KC. Polyclinics must integrate health care vertically and horizontally [editorial]. Lond J Prim Care. 2008;1:42-44.

117. Thomas P, Graffy J, Wallace P, Kirby M. How primary care networks can help integrate academic and service initiatives in primary care. Ann Fam Med. 2006;4(3):235-239.

118. Woolf SH. Social policy as health policy. JAMA. 2009;301(11): 1166-1169.

119. Wilcox R, Knapp A. Building communities that create health Public Health Rep. 2000;115(2-3):139-143.

120. Easwaran E. Meditation: A Simple Eight Point Program For Translating Spiritual Values Into Daily Life. Tomales, CA: Nilgiri Press; 1991.

121. Epstein RM. Mindful practice. JAMA. 1999;282(9):833-839.

122. Epstein RM, Siegel DJ, Silberman J. Self-monitoring in clinical practice: a challenge for medical educators. J Contin Educ Health Prof. 2008;28(1):5-13.

123. Svinte $M$. The promise of personalized medicine: a conversation with Michael Svinte. Interview by Michael Millenson. Health Aff (Millwood). 2006;25(2):w54-w60.

124. Lesko LJ. Personalized medicine: elusive dream or imminent reality? Clin Pharmacol Ther. 2007;81(6):807-816.

125. Aspinall MG, Hamermesh RG. Realizing the promise of personalized medicine. Harv Bus Rev. 2007;85(10):108-117, 165.

126. Kalow W. Pharmacogenetics and pharmacogenomics: origin, status, and the hope for personalized medicine. Pharmacogenomics J. 2006;6(3):162-165.

127. Ferrara J. Personalized medicine: challenges in assessing and capturing value in the commercial environment. Expert Rev Mol Diagn. 2006;6(2):129-131.

128. Langreth R, Waldholz M. New era of personalized medicine: targeting drugs for each unique genetic profile. Oncologist. 1999; 4(5):426-427.

129. Snyderman R, Dinan MA. Improving health by taking it personally. JAMA. Jan 27;303(4):363-364.

130. Coles R. Lives of Moral Leadership. New York, NY: Random House; 2000.

131. Geyman JP. Do Not Resuscitate: Why The Health Insurance Industry is Dying, and How We Must Replace It. Monroe, ME: Common Courage Press; 2008.
132. Patient Centered Primary Care Collaborative. PCPP Pilot Guide: Proof in Practice. A Compilation of Patient Centered Medical Home Pilot and Demonstration Projects. Washington, DC: National Committee for Quality Assurance; 2009;:90.

133. Patient-Centered Primary Care Collaborative. The patient-centered primary care collaborative. http://www.pcpcc.net/.

134. Reid RJ, Fishman PA, Yu O, et al. Patient-centered medical home demonstration: a prospective, quasi-experimental, before and after evaluation. Am J Manag Care. 2009;15(9):e71-e87.

135. Steiner BD, Denham AC, Ashkin E, Newton WP, Wroth T, Dobson LA Jr. Community care of North Carolina: improving care through community health networks. Ann Fam Med. 2008;6(4):361-367.

136. Krist AH, Woolf SH, Frazier CO, et al. An electronic linkage system for health behavior counseling effect on delivery of the $5 \mathrm{~A}^{\prime} \mathrm{s}$. Am J Prev Med. 2008;35(5)(Suppl):S350-S358.

137. Etz RS, Cohen DJ, Woolf $\mathrm{SH}$, et al. Bridging primary care practices and communities to promote healthy behaviors. Am J Prev Med. 2008;35(5)(Suppl):S390-S397.

138. Macaulay AC, Commanda LE, Freeman WL, et al.; North American Primary Care Research Group. Participatory research maximises community and lay involvement. BMJ. 1999;319(7212):774-778.

139. Creating partnerships, improving health: The role of communitybased participatory research. http://www.ahrq.gov/research/cbprrole.htm.

140. Green LA, Graham R, Frey JJ, Stephens GG, eds. Keystone III: The Role of Family Practice in a Changing Health Care Environment: A Dialogue. Washington, DC: The Robert Graham Center, American Academy of Family Physicians; 2001.

141. Thomas S. 'Keystone III' sparks rich discussion on-site and online. AAFP Report. Vol 6; 2000.

142. Green LA, Graham R, Stephens GG, Frey JJ. Special dedication issue: The keystone papers: formal discussion papers from Keystone III. Fam Med. 2001;33(4):230-327.

143. Heath I. Life and death: the growing gap. BMJ. 2007;334(7595): 670.

144. Nutting PA, Miller WL, Crabtree BF, Jaén CR, Stewart EE, Stange KC. Initial lessons from the first national demonstration project on practice transformation to a patient-centered medical home. Ann Fam Med. 2009;7(3):254-260.

145. Nutting PA, Crabtree BF, Stewart EE, et al. Implementing the national demonstration project model of the patient-centered medical home. Ann Fam Med. In press..

146. Nutting PA, Crabtree BF, Miller WL, Stewart EE, Stange KC, Jaén CR. The journey to the patient-centered medical home: A qualitative analysis of the experiences of practices in the national demonstration project. Ann Fam Med. In press.

147. Goroll AH, Berenson RA, Schoenbaum SC, Gardner LB. Fundamental reform of payment for adult primary care: comprehensive payment for comprehensive care. J Gen Intern Med. 2007;22(3):410-415

148. Sandy LG, Bodenheimer T, Pawlson LG, Starfield B. The political economy of U.S. primary care. Health Aff (Millwood). 2009;28(4):1136-1145.

149. Moore LG, Wasson JH, Johnson DJ, Zettek J. The emergence of Ideal Micro Practices for patient-centered, collaborative care. J Ambul Care Manage. 2006;29(3):215-221.

150. Wasson JH, Moore LG. Primary care and community participatory strategies. J Ambul Care Manage. 2009;32(4):299-302.

151. Moore LG, Wasson JH. The ideal medical practice model: improving efficiency, quality and the doctor-patient relationship. Fam Pract Manag. 2007;14(8):20-24.

152. Gunn J, Naccarella L, Palmer V, Kokanovic R, Pope C, Lathlean J. What is the place of generalism in the 2020 primary health care team? Canberra, Australia: Australian Primary Health Care Research Institute, 2007. http://www.anu.edu.au/aphcri/Domain/ Workforce/Gunn_25_approved.pdf Accessed January 31, 2010. 